\title{
Cytokine gene polymorphism associations with congenital cytomegalovirus infection and sensorineural hearing loss
}

\author{
B. Kasztelewicz ${ }^{1}$ (D) - J. Czech-Kowalska ${ }^{2}$ B. Lipka ${ }^{3}$ - B. Milewska-Bobula ${ }^{3}$. \\ M. K. Borszewska-Kornacka ${ }^{4} \cdot$ J. Romańska ${ }^{4} \cdot$ K. Dzierżanowska-Fangrat ${ }^{1}$
}

Received: 2 March 2017 / Accepted: 21 April 2017 / Published online: 13 May 2017

(C) The Author(s) 2017. This article is an open access publication

\begin{abstract}
Cytomegalovirus (CMV) is the most common viral agent of congenital infections and a leading nongenetic cause of sensorineural hearing loss (SNHL). The host immunologic factors that render a developing foetus prone to intrauterine CMV infection and development of hearing loss are unknown. The aim of this study was to assess the potential associations between the polymorphisms within cytokine and cytokine receptors genes, and the risk of congenital CMV infection, and the hearing outcome. A panel of 11 candidate single nucleotide polymorphisms (SNPs): TNF rs1799964, TNF rs1800629, TNFRSF1A rs4149570, IL1B rs16944, IL1B rs1143634, IL10 rs1800896, IL10RA rs4252279, IL12B rs3212227, CCL2 rs1024611, CCL2 rs13900, CCR5 rs333 was genotyped in 470 infants ( 72 with confirmed intrauterine CMV infection and 398 uninfected controls), and related to congenital CMV infection, and the outcome. In multivariate analysis, the IL1B rs16944 TT and TNF rs1799964 TC genotypes were significantly associated with intrauterine CMV
\end{abstract}

Electronic supplementary material The online version of this article (doi:10.1007/s10096-017-2996-6) contains supplementary material, which is available to authorized users.

B. Kasztelewicz

b.kasztelewicz@czd.pl

1 Department of Clinical Microbiology and Immunology, The Children's Memorial Health Institute, Dzieci Polskich 20, 04-730 Warsaw, Poland

2 Department of Neonatology and Neonatal Intensive Care, The Children's Memorial Health Institute, Warsaw, Poland

3 Department of Infant Diseases, The Children's Memorial Health Institute, Warsaw, Poland

4 Department of Neonatology, Warsaw Medical University Hospital, Warsaw, Poland infection $(\mathrm{aOR}=2.32 ; 95 \% \mathrm{CI}, 1.11-4.89 ; p=0.032$, and $\mathrm{aOR}=2.17,95 \% \mathrm{CI}, 1.25-3.77 ; p=0.007$, respectively). Twenty-two out of 72 congenitally infected newborns had confirmed SNHL. Carriers of CT or TT genotype of CCL2 rs 13900 had increased risk of hearing loss at birth and at 6 months of age $(\mathrm{aOR}=3.59 ; p=0.028$ and $\mathrm{aOR}=4.10$; $p=0.039$, respectively). This is the first study to report an association between SNPs in IL1B, TNF, and CCL2, and susceptibility to congenital CMV infection (IL1B and TNF) and SNHL (CCL2).

\section{Introduction}

Human cytomegalovirus (CMV) is a ubiquitous herpes virus. In the majority of healthy adults and children primary infection is asymptomatic, but CMV is an important cause of morbidity and mortality in immunocompromised individuals, and the most common cause of congenital infection worldwide, with a birth prevalence of $0.64 \%$ [1]. Maternal primary infection, reactivation of latent virus or re-infection with an antigenitically diverse strain during pregnancy, can all lead to in utero virus transmission to the developing foetus $[2,3]$. Outcomes following congenital CMV infection are variable, ranging from asymptomatic infection and multiple organ involvement to stillbirth or death in the early neonatal period. Although only $10 \%$ of congenitally-infected neonates have obvious clinical signs at birth, approximately two-thirds of them have permanent neurologic sequelae $[4,5]$. Moreover, even $15 \%$ of asymptomatic children have some type of longterm sequelae. Sensorineural hearing loss (SNHL) is the most common sequel following congenital CMV infection, affecting half of the symptomatic and $10-15 \%$ of the asymptomatic infants [6]. Early diagnosis and prompt intervention (i.e. treatment and rehabilitation) can reduce the long-term sequelae in 
congenitally infected newborns. However, this still remains challenging, as predictors of an adverse outcome, especially in neonates with an asymptomatic infection, have not been well defined.

It is arguable that both viral and host factors are implicated in the pathogenesis of congenital CMV infection. CMV has evolved mechanisms to evade and modulate immune response [7-9]. Evidence from recent studies suggests that CMV affects the cytokine profile within a CMV-infected placenta, at the maternal-foetal interference $[10,11]$. CMV infection during pregnancy has been associated with a shift in cytokine expression toward a proinflammatory state [11]. This in turn may have important consequences for placental development and function, virus transmission, and foetus development [10]. Similarly, the host genetic background may influence the risk and the clinical manifestation of congenital CMV infection. An increasing body of evidence from studies performed mainly in immunocompromised subjects suggests that single nucleotide polymorphisms (SNPs) in genes implicated in immune response may have an impact on the course of CMV infection. A study by Loeffler et al. reported significant associations between SNPs in the IL10 and CCR5 genes, and CMV disease after allogeneic stem cell transplantation [12]. In the same study two SNPs within CCL2 gene encoding monocyte chemoattractant protein 1 were associated with CMV reactivation. Similarly, the 3'UTR polymorphism of the IL12B gene also has been linked with an increased risk of CMV reactivation after kidney transplant [13]. In another study, polymorphisms in the IL10RA gene encoding IL-10 receptor 1 were implicated in CMV retinitis among HIV-infected individuals [14]. Furthermore, a genetic variant in the promoter region of the TNF gene was associated with resistance to CMV infection in adult blood donors [15]. In addition, preliminary findings from studies analysing the role of cytokine polymorphisms in the setting of other herpes virus infections also suggested that genetic variants in IL1 complex, IL10, CCR5, TNF and TNFRSF1A genes could be associated with susceptibility to EBV infection or the pathogenesis of EBVrelated diseases [16-21]. Whether polymorphisms in genes encoding cytokine or cytokine receptors contribute to the risk or the pathogenesis of congenital CMV remains unknown. Detailed knowledge of these polymorphisms in the context of congenital infection may have implications for clinical practice, by a possibility to predict the risk and/or the long-term outcome more accurately and, in turn, allowing appropriate neonatal counselling and the implementation of prompt intervention for newborns at high risk of an adverse outcome.

The aim of the present study was to evaluate the potential impact of the candidate SNPs in genes encoding cytokine and cytokine receptors on the risk of in utero CMV infection and its outcome.

\section{Materials and methods}

\section{Study population}

The study population consisted of 470 infants enrolled prospectively from March 2009 to July 2013 at the Children's Memorial Health Institute in Warsaw, Poland. All subjects were of Caucasian background and were referred from other hospitals in the region. Seventy-two infants had congenital CMV infection confirmed by CMV DNA detection in urine samples collected during the first 2-3 weeks of life (case group). A healthy control group consisted of $398 \mathrm{CMV}-$ uninfected children. All infants included in the study had whole blood sample available for a genotyping study. Children with probable postnatal infection (i.e. diagnosed after the third week of life), genetic disorders or congenital infections not related to CMV were excluded.

All infants with congenital CMV infection underwent complete physical examination, ophthalmologic and hearing evaluation, and cranial ultrasonography and/or computer tomography $(\mathrm{CT})$. SNHL was defined as air conduction thresholds $>25 \mathrm{dBHL}$ on the auditory brainstem response (ABR) with normal bone conduction thresholds and normal middle ear function. Congenitally infected infants were classified as symptomatic on the basis of the presence of at least one of the following clinical findings at birth: petechiae, cholestatic jaundice (with direct bilirubin level $>2 \mathrm{mg} / \mathrm{dL}$ ), hepatosplenomegaly, thrombocytopenia $(<85,000$ cells/ $\mathrm{mm}^{3}$ ), intracranial calcification, microcephaly, seizures, chorioretinitis, or other abnormal CT findings (e.g. cerebral atrophy and/or malformations, periventricular cysts, ventriculomegaly). To evaluate the severity of congenital CMV disease an illness score was calculated for each child, one point being awarded for each sign and symptom.

\section{DNA isolation}

Total genomic DNA was extracted from $200 \mu \mathrm{L}$ of clinical specimen (whole blood, urine and cerebrospinal fluid) using QIAamp DNA Mini kit (Qiagen Inc., Hilden, Germany) according to the manufacturer's instructions, with final elution of $100 \mu \mathrm{L}$.

\section{Detection of CMV DNA}

The presence of CMV DNA was evaluated primarily in urine samples. In addition, children with congenital CMV infection (i.e. tested positive for CMV DNA in urine within the first 23 weeks of life) had CMV DNA tested in whole blood and some of them also in CSF, if clinically indicated. The presence of CMV DNA in clinical specimens was detected by qualitative real-time PCR using the SYBRGreen I format and primers set located in the lower matrix phosphoprotein 
(UL83) gene (Forward: 5' TCTCGCACATCATGCTGGAT 3' and Reverse: 5' CGTTCATCAACAGGTTACCTGAGAT 3'). The PCR was performed on the 7500 Real-Time PCR System (Applied Biosystems, Inc., Foster City, CA, USA) in a total volume of $25 \mu \mathrm{L}$ in the presence of $5 \mu \mathrm{L}$ of DNA sample, $12.5 \mu \mathrm{L}$ of SYBRGreen PCR MasterMix (Applied Biosystems) and $250 \mathrm{nM}$ of each of the UL83 primers. The temperature profile was $95^{\circ} \mathrm{C}$ for $10 \mathrm{~min}, 40$ cycles at $95^{\circ} \mathrm{C}$ for $15 \mathrm{~s}$ and $60{ }^{\circ} \mathrm{C}$ for $60 \mathrm{~s}$. At the end of each run, a melting curve analysis was performed. The melting temperature range for CMV DNA positive samples was $81.5 \pm 0.5{ }^{\circ} \mathrm{C}$. The sensitivity of the assay was 0.99 copies/reaction.

\section{Determination of SNP genotypes}

SNPs genotyping was performed using genomic DNA extracted from whole blood. Eleven SNPs in eight candidate genes were selected a priori on the basis of the following criteria: a minor allele frequency of $>5 \%$ in the Pubmed SNP database (dbSNP) for Caucasian population (HapMap CEU or CAUC1), previous associations with infectious diseases or a plausible contribution to CMV diseases (i.e. SNPs within genes implicated in eliciting virus specific immune response and/or genes targeted by CMV in their immune evasion strategy). Briefly, TaqMan SNP Predesigned Genotyping Assays (Applied Biosystems, Inc., Foster City, CA, USA) were applied for: TNF rs1799964 (-1031 T/C), TNF rs1800629 (-308 G/A), TNFRSF1A rs4149570 (-201 C/A), CCL2 rs13900 (+1543 C/T), IL10 rs1800896 (-1082 A/G) and IL10RA rs4252279 $(+5964 \mathrm{C} / \mathrm{T})$ polymorphisms. The allelic discrimination was performed on the 7500 Real-time PCR System (Applied Biosystems) according to the manufacturer's instructions. SNPs of IL1B rs16944 (-511C/T), IL1B rs1143634 (+3954 C/T), IL12B rs3212227 (3'UTR A/C), and CCL2 rs1024611 (-2518 A/G) were assessed by PCR and restriction fragment length polymorphism, as previously reported [13, 22-24]. The presence of 32-base pair deletions within the CCR5 gene (rs333, CCR5 $\Delta 32$ ) were analysed by PCR [25]. A blinded duplicated analysis of 25 random study samples demonstrated $100 \%$ concordance.

\section{Statistical analysis}

Quantitative data were expressed as mean \pm standard deviation (SD) or the median and interquartile range (IQR) if nonnormally distributed. Categorical variables were compared using the $\chi^{2}$ test or Fisher exact test. Continuous variables were compared using the Student t-test or Mann-Whitney Utest. All SNPs were analysed for Hardy-Weinberg equilibrium (HWE) by using the $\chi^{2}$ test ( 1 degree of freedom). The association between SNP genotype and congenital CMV infection or SNHL was analysed by co-dominant, dominant, recessive and over-dominant models. The genetic model that best fitted the data for each SNP was chosen based on the Akaike information criterion (AIC). The model with the lowest AIC value was the best model [26]. Odds ratios (ORs) with $95 \%$ confidence intervals (CIs) for each model were calculated using logistic regression. Linkage disequilibrium (LD) between multiple loci was measured using the standardized disequilibrium coefficient (D') and the correlation coefficient $\left(\mathrm{r}^{2}\right)$. The analysis haplotype frequencies was performed using the expectation-maximization algorithm. The association, HWE, LD and haplotype analyses were made by the SNPStats online tool [26]. Otherwise, statistical analyses were performed using Statistica software version 6.0 (StatSoft. Inc., Tulsa, USA). No correction was made for multiple testing. A two-tailed $p$-value of $\leq 0.05$ was considered significant.

\section{Results}

\section{Study population characteristics}

The demographic and clinical characteristics of infants with congenital CMV infection $(n=72)$ and the uninfected control group ( $n=398)$ are shown in Table 1 . Infants with congenital CMV infection (as shown by detection of DNA in urine within the first 3 weeks of life) were more likely to be born to younger mothers. There were no differences between the two groups with respect to gender or gestational age (completed weeks).

At the time of the diagnosis, viral DNA was also detected in whole blood in 53 out of 72 infants with congenital CMV infection $(73.6 \%)$ and in cerebrospinal fluid in 14 out of 56 tested $(25 \%)$. At least one clinical finding suggestive of congenital CMV infection was found in 61 (84.7) infants (symptomatic CMV infection), whereas 11 (15.3\%) infants were asymptomatic at birth. The illness scores in symptomatic infants ranged from 1 to 8 (median 3) (Table 2).

The overview of hearing evaluation in infants with congenital CMV infection is shown in Fig. 1. All infants with congenital CMV infection had universal screening test by a transient otoacoustic emissions (OAE) test performed during the first month of life (median age of testing was 12 days, IQR: 2.5-32 days). Additionally, at least one ABR assessment (mean 3, range 1-10) was performed in 56 out of 72 infants with congenital CMV infection. The results of ABR were unavailable in 16 infants. The median age at initial ABR testing was 1.45 months (IQR: 1.1-3.5 months). Of the 72 infants with congenital CMV infection, 27 failed a universal screening test by OAE after birth. Twenty-two infants who failed a screening hearing test had confirmed early-onset SNHL by ABR (except one all these infants were symptomatic at birth), the remaining four had normal hearing (all symptomatic at birth) and one (asymptomatic at birth) had no ABR data available. In all 22 infants with SNHL, ABR confirmed hearing 
Table 1 Characteristics of children with congenital CMV infection $(n=72)$ and healthy control group $(n=398)$

\begin{tabular}{llll}
\hline Characteristics & $\begin{array}{l}\text { Congenital CMV } \\
(n=72)\end{array}$ & $\begin{array}{l}\text { Healthy control } \\
(n=398)\end{array}$ & $P$-value $^{\mathrm{a}}$ \\
\hline $\begin{array}{l}\text { Male, } n(\%) \\
\text { Gestational age, median (IQR), weeks }\end{array}$ & $38(52.7)$ & $219(55.0)$ & 0.06 \\
$\begin{array}{l}\text { Prematurity (<37 weeks), (\%) } \\
\text { Maternal age at delivery }\end{array}$ & $13(37-40)$ & $39(38-40)$ & 0.22 \\
$\quad \begin{array}{l}\text { Mean ( } \pm \text { SD), year } \\
\text { Maternal CMV serostatus at delivery, }(\%)\end{array}$ & $26.77 \pm 4.63$ & $82(20.6)$ & 0.62 \\
$\quad$ Naive & NA & $29.89 \pm 5.26$ & 0.00001 \\
$\quad$ Immune & $72(100)$ & $75(18.8)$ & NA \\
\hline
\end{tabular}

$C M V$ human cytomegalovirus, $I Q R$ interquartile range, $S D$ standard deviation, $N A$ not applicable

${ }^{a} \chi^{2}$ test, Mann-Whitney U-test and Student's t-test were performed when appropriate loss in the same ear in which OAE testing failed, suggesting that hearing loss was present at birth. Among 45 infants who passed a hearing screening test (36 symptomatic at birth), 30 infants had normal hearing thresholds in the ABR test (24 infants symptomatic at birth). Forty-two infants had followup data available at 6 months of age, i.e., in 15 infants, earlyonset SNHL was diagnosed and 27 infants had normal hearing at 6 months of age.

Table 2 Clinical and laboratory abnormalities at birth in infants with congenital CMV infection $(n=72)$

\begin{tabular}{ll}
\hline Finding & $\begin{array}{l}\text { Occurrences, } \\
n(\%)\end{array}$ \\
\hline Cholestatic jaundice (direct bilirubin level $>2 \mathrm{mg} / \mathrm{dL})$ & $19(26.4)$ \\
$\quad$ Petachial rash & $17(23.6)$ \\
Hepatosplenomegaly & $26(36.1)$ \\
Seizures & $5(6.9)$ \\
Thrombocytopenia $\left(<85,000\right.$ cells $\left./ \mathrm{mm}^{3}\right)$ & $30(41.7)$ \\
Microcephaly & $15(20.8)$ \\
Intracranial calcifications & $31(43.1)$ \\
Other abnormal cranial findings ${ }^{\mathrm{a}}$ & $45(62.5)$ \\
Small for gestational age & \\
Number of findings (illness score) & $24(33.3)$ \\
At least one finding (i.e. child was symptomatic) & $61(84.7)$ \\
1 & $15(20.8)$ \\
2 & $14(19.4)$ \\
$\geq 3^{\mathrm{c}}$ & $32(44.4)$ \\
\hline
\end{tabular}

${ }^{\text {a }}$ Including: cerebral atrophy and/or malformations, periventricular cysts

${ }^{\mathrm{b}}$ SGA, birth weight $<10$ th percentile for gestational age (children with SGA without other findings were considered as asymptomatic)

${ }^{\mathrm{c}}$ The median illness score was 3 ; more specifically, an illness score of 3 was found in seven $(9.7 \%$ ) children, a score of 4 in eight (11.1\%), score 5 in nine $(12.5 \%)$, score 6 in four $(5.6 \%)$, score 7 in three $(4.2 \%)$ and score 8 in one $(1.4 \%)$ child

\section{Results of SNP genotyping}

Eleven candidate SNPs were genotyped in 470 children. All SNPs achieved over 99\% successful genotyping. Genotype frequency distribution in children with congenital CMV and the healthy control group are listed in Supplementary Table S1. All SNPs were in HWE in a study population $(p>0.05)$.

\section{Associations of SNPs with in utero CMV infection}

When genotype distributions in infants with congenital CMV infection were compared with uninfected controls, significant associations for IL1B rs16944 (IL1B $-511 \mathrm{C} / \mathrm{T}$ ) and TNF rs1799964 (-1031 C/T) polymorphisms were found (Table 3). The rare IL1B -511 TT genotype was overrepresented in infants with congenital CMV infection compared to controls $(\mathrm{OR}=2.52 ; 95 \% \mathrm{CI}, 1.25-5.08 ; p=0.014)$. This association remained significant when adjusted for mother's CMV status and age at delivery (OR $=2.32$; 95\% CI, 1.11 4.89; $p=0.032$ ). Regarding TNF rs1799964 polymorphism, significantly higher frequency of heterozygous TC genotype was observed in infants with congenital CMV infection than in the control group $(\mathrm{OR}=2.15 ; 95 \% \mathrm{CI}, 1.27-3.63 ; p=0.005$ and $\mathrm{OR}=2.17 ; 95 \% \mathrm{CI}, 1.25-3.77 ; p=0.007$, for unadjusted and adjusted regression model, respectively). For other SNPs analysed, the genotype distributions were similar, both in the congenital CMV infection group and the controls (Supplementary Table S1).

\section{Association between SNP and hearing outcome in congenitally-infected infants}

Taking into account the clinical outcome of congenital CMV infection, no significant association was found between severity of congenital CMV disease (i.e. illness score) and SNPs (Supplementary Table S2). However, when association 


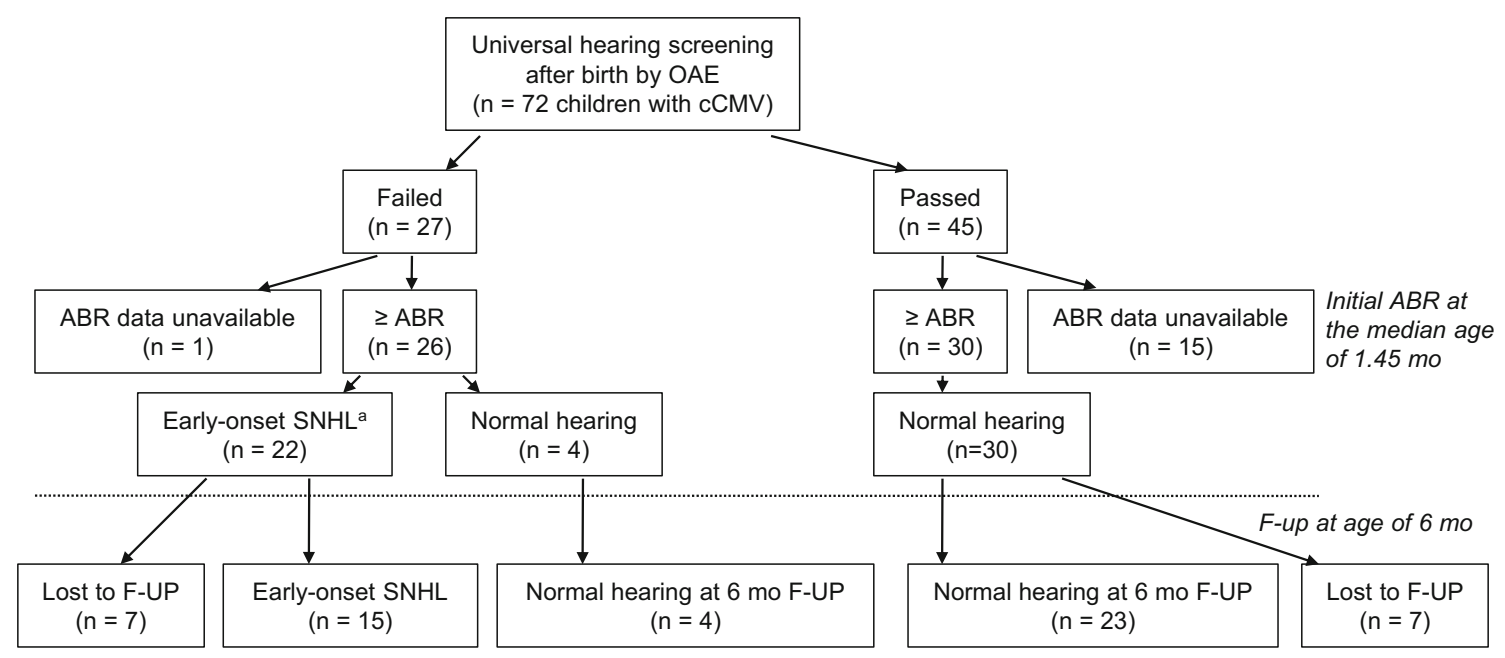

Fig. 1 Overview of infants with congenital CMV infection according to hearing outcome. $O A E$ otoacoustic emissions, $c C M V$ congenital CMV infection, F-UP follow-up, $A B R$ auditory brainstem response, $S N H L$ sensorineural hearing loss ${ }^{\text {a }}$ In all 22 children, ABR confirmed hearing loss in the same ear in which OAE testing failed, suggesting that hearing loss was present at birth; eight infants with unilateral SNHL (profound, $n=5$; moderate, $n=2$; and mild, $n=1$ ) and 14 infants with bilateral SNHL (profound, $n=8$; severe, $n=1$; moderate, $n=4$; mild, $n=1$; all refer to the better ear). Hearing thresholds assessed with the ABR were defined as follows: a threshold of 0-25 dB for normal hearing, 26-40 dB for mild hearing loss, $41-60 \mathrm{~dB}$ for moderate hearing loss, $61-80 \mathrm{~dB}$ for severe hearing loss and $>80$ for profound hearing loss analysis was performed according to hearing outcome at birth as well as at the age of 6 months, a significant relation between polymorphisms within CCL2 gene (rs 13900) and SNHL was observed (Table 4). In particular, infants carrying CT or TT genotype of CCL2 rs13900 were statistically more likely to develop SNHL compared to infants with CC genotype $(\mathrm{OR}=3.38 ; 95 \% \mathrm{CI}, 1.06-10.74, p=0.033$ and $\mathrm{OR}=4.0$, 95\% CI: $1.01-15.87, p=0.04$, for hearing status at birth and at the age of 6 months, respectively). These associations remained significant after adjusting for variable symptoms at birth $(\mathrm{OR}=3.59 ; 95 \% \mathrm{CI}, 1.10-11.73, p=0.028$ and $\mathrm{OR}=4.10,95 \% \mathrm{CI}, 1.01-16.59, p=0.039$ for hearing status at birth and at the age of 6 months, respectively).

With regard to the second SNP within the CCL2 gene (rs1024611) analysed in the present study, an increased frequency of $\mathrm{AG}$ and $\mathrm{GG}$ genotypes was found in infants with SNHL when compared to those with normal hearing at birth $(\mathrm{OR}=3.06 ; 95 \% \mathrm{CI}, 0.99-9.45, p=0.046$ and $\mathrm{OR}=3.33 ; 95 \% \mathrm{CI}, 1.05-10.62, p=0.036$, for unadjusted and adjusted regression model, respectively). However, when association analysis was performed in a smaller group of infants with follow-up data available at the age of 6 month, the difference was not statistically significant $(\mathrm{OR}=3.40 ; 95 \% \mathrm{CI}, 0.90-12.83, p=0.064$ and $\mathrm{OR}=3.59 ; 95 \% \mathrm{CI}, 0.93-13.90, p=0.057$, for unadjusted and adjusted regression model, respectively). Given the close proximity of the two SNPs analysed within the CCL2 gene, linkage disequilibrium is highly probable. LD analysis confirmed a strong disequilibrium between rs1024611 and rs13900 SNPs in the CCL2 gene, with $D^{\prime}=1$ and $r^{2}=0.96$. Subsequently performed haplotype analysis revealed increased frequency of rs1024611rs13900 G-T haplotype of CCL2 in infants with SNHL compared to the most frequent haplotype $\mathrm{AC}$, but the

Table 3 Associations of IL1B rs16944 (-511 C/T) and TNF rs1799964 (-1031 T/C) polymorphism with congenital CMV infection

\begin{tabular}{|c|c|c|c|c|c|c|c|}
\hline \multirow{2}{*}{$\begin{array}{l}\text { Polymorphism SNP } \\
\text { database ID number }\end{array}$} & \multirow[t]{2}{*}{ Genotype } & \multicolumn{2}{|l|}{ Children, n (\%) } & \multicolumn{2}{|c|}{ Unadjusted analysis } & \multicolumn{2}{|l|}{ Adjusted analysis } \\
\hline & & $\begin{array}{l}\text { Congenital CMV } \\
(n=72)\end{array}$ & $\begin{array}{l}\text { Healthy control } \\
(n=398)\end{array}$ & OR $(95 \% \mathrm{CI})$ & $P$-value & OR $(95 \% \mathrm{CI})$ & $P$-value ${ }^{\mathrm{a}}$ \\
\hline IL1B rs16944 & $\begin{array}{l}\mathrm{CC}+\mathrm{CT} \\
\mathrm{TT}\end{array}$ & $\begin{array}{l}59(81.9) \\
13(18.1)\end{array}$ & $\begin{array}{l}366(92) \\
32(8)\end{array}$ & $\begin{array}{l}1 \\
2.52(1.25-5.08)\end{array}$ & 0.014 & $\begin{array}{l}1 \\
2.32(1.11-4.89)\end{array}$ & 0.032 \\
\hline TNF rs1799964 & $\begin{array}{l}\mathrm{TT}+\mathrm{CC} \\
\mathrm{TC}\end{array}$ & $\begin{array}{l}43(59.7) \\
29(40.3)\end{array}$ & $\begin{array}{l}303(76.1) \\
95(23.9)\end{array}$ & $\begin{array}{l}1 \\
2.15(1.27-3.63)\end{array}$ & 0.005 & $\begin{array}{l}1 \\
2.17(1.25-3.77)\end{array}$ & 0.007 \\
\hline
\end{tabular}

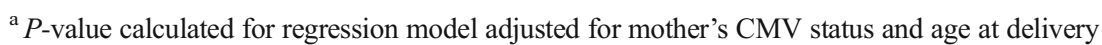


Table 4 Association of CCL2 rs13900 and rs1024611 polymorphisms with congenial CMV-related sensorineural hearing loss (SNHL) at birth and at the age of 6 months follow-up

\begin{tabular}{|c|c|c|c|c|c|c|c|}
\hline Hearing status by $\mathrm{ABR}$ & CCL2 genotype ${ }^{a}$ & $\begin{array}{l}\text { SNHL } \\
n(\%)\end{array}$ & $\begin{array}{l}\text { Normal hearing } \\
n(\%)\end{array}$ & OR $(95 \% \mathrm{CI})$ & $P$ - value & OR $(95 \% \mathrm{CI})$ & $P$ - value ${ }^{\mathrm{b}}$ \\
\hline \multicolumn{8}{|l|}{ At birth $(n=56)$} \\
\hline rs 13900 & $\begin{array}{l}\mathrm{CC} \\
\mathrm{CT} / \mathrm{TT}\end{array}$ & $\begin{array}{l}6(27.3) \\
16(72.7)\end{array}$ & $\begin{array}{l}19(55.9) \\
15(44.1)\end{array}$ & $\begin{array}{l}1 \\
3.38(1.06-10.74)\end{array}$ & 0.033 & $\begin{array}{l}1 \\
3.59(1.10-11.73)\end{array}$ & 0.028 \\
\hline rs1024611 & $\begin{array}{l}\mathrm{AA} \\
\mathrm{AG} / \mathrm{GG}\end{array}$ & $\begin{array}{l}7(31.8) \\
15(68.2)\end{array}$ & $\begin{array}{l}20(58.8) \\
14(41.2)\end{array}$ & $\begin{array}{l}1 \\
3.06(0.99-9.45)\end{array}$ & 0.046 & $3.33(1.05-10.62)$ & 0.036 \\
\hline \multicolumn{8}{|c|}{ At the age of 6 months $(n=42)$} \\
\hline rs 13900 & $\begin{array}{l}\mathrm{CC} \\
\mathrm{CT} / \mathrm{TT}\end{array}$ & $\begin{array}{l}4(26.7) \\
11(73.3)\end{array}$ & $\begin{array}{l}16(59.3) \\
11(40.7)\end{array}$ & $\begin{array}{l}1 \\
4.0(1.01-15.87)\end{array}$ & 0.04 & $\begin{array}{l}1 \\
4.10(1.01-16.59)\end{array}$ & 0.039 \\
\hline rs1024611 & $\begin{array}{l}\mathrm{AA} \\
\mathrm{AG} / \mathrm{GG}\end{array}$ & $\begin{array}{l}5(33.3) \\
10(66.7)\end{array}$ & $\begin{array}{l}17(63) \\
10(37)\end{array}$ & $\begin{array}{l}1 \\
3.40(0.90-12.83)\end{array}$ & 0.064 & $\begin{array}{l}1 \\
3.59(0.93-13.90)\end{array}$ & 0.057 \\
\hline
\end{tabular}

${ }^{a}$ Strong linkage disequilibrium was observed between two SNP in the CCL2 gene rs13900 and rs1024611, (D' $=1, \mathrm{r}^{2}=0.96$ )

${ }^{\mathrm{b}} P$-value calculated for regression model adjusted for variable symptoms at birth

difference was not statistically significant $(\mathrm{OR}=2.33$; 95\% CI, 0.96-5.64, $p=0.067$ ).

Genotype distribution of the remaining investigated SNPs did not show any significant difference between infants with congenital CMV infection and SNHL or normal hearing (Supplementary Table S3).

\section{Discussion}

Genetic polymorphism in cytokine genes may lead to an altered immune response and, in turn, influence the risk or the outcome of an infectious disease [27]. While a number of investigators have reported relationships between genetic polymorphisms within cytokine or cytokine gene receptors and the CMV infection among immunosuppressed individuals, such as transplant recipients or AIDS patients [12-14], the role of such polymorphisms has not been studied in the setting of congenital CMV infection.

This is the first report on the relation between SNPs within cytokine and cytokine receptors and the risk of congenital CMV infection, and SNHL. Two novel observations arose from the present study. First, an association between SNPs rs16944 and rs1799964 located within the promoter region of IL1B (position 511) and TNF (position 1031) genes, respectively, and the susceptibility to in utero CMV infection were found. In particular, foetuses carrying a rare homozygous TT genotype of IL1B -511 are at over two-fold higher risk of congenital CMV infection compared to other IL1B -511 genotypes. Similarly, the heterozygous genotype of TNF rs1799964 was associated with an over two-fold increased risk of congenital CMV infection compared to other TNF -1031 genotypes. Taking into account the fact that the minor $\mathrm{T}$ allele of IL1B -511 renders high IL-1 $\beta$ producer phenotype with more severe and prolonged inflammatory response [28-30], and that polymorphism at -1031 of the TNF gene has been associated with enhanced expression of this cytokine [31], with increased frequency of these genotypes observed in congenitally infected children compared to healthy controls, suggests that a strong inflammatory response may make the foetus more prone to CMV infection. This is in line with previous studies from infected amniotic fluids and placentae showing that CMV infection leads to a proinflammatory (Th1) shift in cytokine profiles with a potential implication for the pathogenesis of foetal disease $[10,11]$. However, due to pleiotropic properties of IL- $1 \beta$ and TNF- $\alpha$, interactions between semi-allogenic placenta and the maternal immune system, the exact mechanism of the link between the genetic polymorphisms of IL1B and TNF genes, and the susceptibility to in utero CMV infection needs further examination in functional studies.

Second, a link between rs13900 polymorphisms within the CCL2 gene (encoding monocyte chemoattractant protein-1, MCP-1) and the hearing outcome of congenital CMV infection was observed. Carriers of minor homozygous and heterozygous genotypes of CCL2 rs13900 (at position +1543) were at significantly higher risk of developing SNHL as compared to common homozygotes. There was also association with CCL2 rs1024611 polymorphisms (at position -2518) and hearing outcome at birth. However this association failed to be significant when analyses were performed in a smaller group of infants with audiological data available at the age of 6 months. In accordance with the previous study, rs1024611 and rs13900 were in strong linkage disequilibrium [32], and subsequent haplotype analysis revealed a trend for increased frequency of rs1024611-rs13900 G-T haplotype of CCL2 in infants with SNHL. Recently, a robust functional study demonstrated that the haplotype containing the 
rs $1024611 \mathrm{G}$ allele is associated with increased CCL2 expression [32]. Consistent with this, the polymorphisms in the CCL2 gene have been linked to increased MCP-1 levels in cerebrospinal fluid and monocyte infiltration of brain tissue in HIV-1 associated neurological disorders [33]. As the pathology of underlying SNHL is not fully understood, similarly the exact mechanism by which the polymorphisms in CCL2 might increase the risk of SNHL is currently unknown. Studies in animal models as well as findings in human temporal bones have consistently indicated that hearing loss following congenital CMV infection could have a significant inflammatory component $[34,35]$. A recent study in a murine model of CMV-inducted hearing loss revealed that elevated expression of the subset of proinflammatory chemokines, which contribute to mononuclear cell infiltration into murine CMV infected cochlear cells rather than a virus mediated cytopathology, are responsible for hearing loss [34]. Further studies in a larger population of infants with SNHL as well as functional ones are required to confirm the link between the CCL2 polymorphisms and the risk of SNHL development. Until then, the mechanistic explanation of the potential link between SNPs in the cytokine genes and the outcome of congenital CMV infection presented here remains purely speculation.

If confirmed in larger prospective studies, these findings may have important implications. First, the interventions that modulate host inflammatory response could provide a promising therapeutic strategy for CMV infection. Second, the CCL2 genotype might be used as a diagnostic marker to identify individuals at risk of developing CMV-associated SNHL and perhaps to target them for early therapy and/or rehabilitation.

This study has some limitations. First, the rate of maternofoetal transmission may be influenced by gestational age at the time of maternal infection and viral load in the amniotic fluid, and these data were unavailable in this study. Second, as in the other studies of this type, it could not be excluded that the observed associations are due to a linkage with other, as yet unknown SNPs. Third, it should be noted that this data set was not adjusted for multiple testing, and so type 1 error cannot be completely ruled out. Finally, the analysis of association between SNPs in the CCL2 gene and hearing loss involved only infants with early-onset SNHL. These results require confirmation in large sized and longitudinal studies to be certain of the associations, as hearing loss in congenitally infected children may be progressive or have delayed onset.

In conclusion, the results of the present study suggest for the first time that polymorphisms in cytokine genes may influence the pathogenesis of congenital CMV infection. It has been shown that genetic polymorphisms in IL1B and TNF may modulate the susceptibility to intrauterine CMV infection, whereas CCL2 polymorphisms may influence the hearing outcome in children with congenital CMV infection.
Further, larger studies and functional assessment of the SNPs are required to confirm their pathogenic role.

Compliance with ethical standards All procedures performed in studies involving human participants were in accordance with the ethical standards of the institutional and/or national research committee and with the 1964 Helsinki declaration and its later amendments or comparable ethical standards. The study protocol has been approved by the Ethics Committee of the Children's Memorial Health Institute.

Funding This study was supported by the European Regional Development Fund under Operational Programme Innovative Economy, Grant No. POIG.01.01.02-10-107/09 and Iceland, Liechtenstein and Norway through the EEA Financial Mechanism, Grant No. PL0270.

Conflict of interest The authors declare that they have no conflict of interest.

Informed consent Informed consent was obtained from all mothers or legal guardians. This article does not contain any studies with animals performed by any of the authors.

Open Access This article is distributed under the terms of the Creative Commons Attribution 4.0 International License (http:// creativecommons.org/licenses/by/4.0/), which permits unrestricted use, distribution, and reproduction in any medium, provided you give appropriate credit to the original author(s) and the source, provide a link to the Creative Commons license, and indicate if changes were made.

\section{References}

1. Kenneson A, Cannon MJ (2007) Review and meta-analysis of the epidemiology of congenital cytomegalovirus (CMV) infection. Rev Med Virol 17(4):253-276

2. Boppana SB, Rivera LB, Fowler KB, Mach M, Britt WJ (2001) Intrauterine transmission of cytomegalovirus to infants of women with preconceptional immunity. N Engl J Med 344(18):1366-1371

3. Soper DE (2013) Congenital cytomegalovirus infection: an obstetrician's point of view. Clin Infect Dis 57(Suppl 4):S171-S173

4. Boppana SB, Ross SA, Fowler KB (2013) Congenital cytomegalovirus infection: clinical outcome. Clin Infect Dis 57(Suppl 4):S178-S181

5. Dollard SC, Grosse SD, Ross DS (2007) New estimates of the prevalence of neurological and sensory sequelae and mortality associated with congenital cytomegalovirus infection. Rev Med Virol 17(5):355-363

6. Fowler KB (2013) Congenital cytomegalovirus infection: audiologic outcome. Clin Infect Dis 57(Suppl 4):S182-S184

7. Mocarski ES (2002) Immunomodulation by cytomegaloviruses: manipulative strategies beyond evasion. Trends Microbiol 10(7): 332-339

8. Noriega V, Redmann V, Gardner T, Tortorella D (2012) Diverse immune evasion strategies by human cytomegalovirus. Immunol Res 54(1-3):140-151

9. Noriega VM, Haye KK, Kraus TA, Kowalsky SR, Ge Y, Moran TM, Tortorella D (2014) Human cytomegalovirus modulates monocyte-mediated innate immune responses during short-term experimental latency in vitro. J Virol 88(16):9391-9405

10. Hamilton ST, Scott G, Naing Z, Iwasenko J, Hall B, Graf N, Arbuckle S, Craig ME, Rawlinson WD (2012) Human cytomegalovirus-induces cytokine changes in the placenta with implications for adverse pregnancy outcomes. PLoS One 7(12):e52899 
11. Scott GM, Chow SS, Craig ME, Pang CN, Hall B, Wilkins MR, Jones CA, Lloyd AR, Rawlinson WD (2012) Cytomegalovirus infection during pregnancy with maternofetal transmission induces a proinflammatory cytokine bias in placenta and amniotic fluid. J Infect Dis 205(8): 1305-1310

12. Loeffler J, Steffens M, Arlt EM, Toliat MR, Mezger M, Suk A, Wienker TF, Hebart H, Nürnberg P, Boeckh M, Ljungman $\mathrm{P}$, Trenschel R, Einsele H (2006) Polymorphisms in the genes encoding chemokine receptor 5 , interleukin-10, and monocyte chemoattractant protein 1 contribute to cytomegalovirus reactivation and disease after allogeneic stem cell transplantation. J Clin Microbiol 44(5):1847-1850

13. Hoffmann TW, Halimi JM, Büchler M, Velge-Roussel F, Goudeau A, Al Najjar A, Boulanger MD, Houssaini TS, Marliere JF, Lebranchu Y, Baron C (2008) Association between a polymorphism in the IL-12p40 gene and cytomegalovirus reactivation after kidney transplantation. Transplantation 85(10):1406-1411

14. Sezgin E, Jabs DA, Hendrickson SL, Van Natta M, Zdanov A, Lewis RA, Smith MW, Troyer JL, O’Brien SJ, Group SR (2010) Effect of host genetics on the development of cytomegalovirus retinitis in patients with AIDS. J Infect Dis 202(4):606-613

15. Hurme M, Helminen M (1998) Resistance to human cytomegalovirus infection may be influenced by genetic polymorphisms of the tumour necrosis factor-alpha and interleukin-1 receptor antagonist genes. Scand J Infect Dis 30(5):447-449

16. McAulay KA, Haque T, Crawford DH (2009) Tumour necrosis factor gene polymorphism: a predictive factor for the development of post-transplant lymphoproliferative disease. Br J Cancer 101(6): 1019-1027

17. Babel N, Vergopoulos A, Trappe RU, Oertel S, Hammer MH, Karaivnanov S, Schneider N, Riess H, Papp-Vary M, Neuhaus R, Gondek LP, Volk H-D, Reinke P (2007) Evidence for genetic susceptibility towards development of posttransplant lymphoproliferative disorder in solid organ recipients. Transplantation 84(3):387-391

18. Bogunia-Kubik K, Jaskula E, Lange A (2007) The presence of functional CCR5 and EBV reactivation after allogeneic haematopoietic stem cell transplantation. Bone Marrow Transplant 40(2):145-150

19. zur Hausen A, Crusius JB, Murillo LS, Alizadeh BZ, Morré SA, Meijer CJ, van den Brule AJ, Peña AS (2003) IL-1B promoter polymorphism and Epstein-Barr virus in Dutch patients with gastric carcinoma. Int J Cancer 107(5):866-867

20. Hurme M, Helminen M (1998) Polymorphism of the IL-1 gene complex in Epstein-Barr virus seronegative and seropositive adult blood donors. Scand J Immunol 48(3):219-222

21. Helminen ME, Kilpinen S, Virta M, Hurme M (2001) Susceptibility to primary Epstein-Barr virus infection is associated with interleukin-10 gene promoter polymorphism. J Infect Dis 184(6): 777-780

22. Hurme M, Santtila S (1998) IL-1 receptor antagonist (IL-1Ra) plasma levels are co-ordinately regulated by both IL-1Ra and IL-1beta genes. Eur J Immunol 28(8):2598-2602

23. Bioque G, Crusius JB, Koutroubakis I, Bouma G, Kostense PJ, Meuwissen SG, Peña AS (1995) Allelic polymorphism in IL-1 beta and IL-1 receptor antagonist (IL-1Ra) genes in inflammatory bowel disease. Clin Exp Immunol 102(2):379-383

24. Szalai C, Duba J, Prohászka Z, Kalina A, Szabó T, Nagy B, Horváth L, Császár A (2001) Involvement of polymorphisms in the chemokine system in the susceptibility for coronary artery disease (CAD). Coincidence of elevated $\mathrm{Lp}(\mathrm{a})$ and MCP-1 $-2518 \mathrm{G} / \mathrm{G}$ genotype in CAD patients. Atherosclerosis 158(1):233-239

25. Abdi R, Tran TB, Sahagun-Ruiz A, Murphy PM, Brenner BM, Milford EL, McDermott DH (2002) Chemokine receptor polymorphism and risk of acute rejection in human renal transplantation. $\mathrm{J}$ Am Soc Nephrol 13(3):754-758

26. Sole X, Guino E, Valls J, Iniesta R, Moreno V (2006) SNPStats: a web tool for the analysis of association studies. Bioinformatics 22(15):1928-1929

27. Bidwell J, Keen L, Gallagher G, Kimberly R, Huizinga T, McDermott MF, Oksenberg J, McNicholl J, Pociot F, Hardt C, D'Alfonso S (1999) Cytokine gene polymorphism in human disease: on-line databases. Genes Immun 1(1):3-19

28. El-Omar EM, Carrington M, Chow WH, McColl KE, Bream JH, Young HA, Herrera J, Lissowska J, Yuan CC, Rothman N, Lanyon G, Martin M, Fraumeni JF, Rabkin CS (2001) The role of interleukin-1 polymorphisms in the pathogenesis of gastric cancer. Nature 412(6842):99

29. Chen H, Wilkins LM, Aziz N, Cannings C, Wyllie DH, Bingle C, Rogus J, Beck JD, Offenbacher S, Cork MJ, Rafie-Kolpin M, Hsieh CM, Kornman KS, Duff GW (2006) Single nucleotide polymorphisms in the human interleukin-1B gene affect transcription according to haplotype context. Hum Mol Genet 15(4):519-529

30. Hall SK, Perregaux DG, Gabel CA, Woodworth T, Durham LK, Huizinga TW, Breedveld FC, Seymour AB (2004) Correlation of polymorphic variation in the promoter region of the interleukin-1 beta gene with secretion of interleukin-1 beta protein. Arthritis Rheum 50(6):1976-1983

31. Higuchi T, Seki N, Kamizono S, Yamada A, Kimura A, Kato H, Itoh K (1998) Polymorphism of the 5'-flanking region of the human tumor necrosis factor (TNF)-alpha gene in Japanese. Tissue Antigens 51(6):605-612

32. Pham MH, Bonello GB, Castiblanco J, Le T, Sigala J, He W, Mummidi S (2012) The rs 1024611 regulatory region polymorphism is associated with CCL2 allelic expression imbalance. PLoS One 7(11):e49498

33. Letendre S, Marquie-Beck J, Singh KK, de Almeida S, Zimmerman J, Spector SA, Grant I, Ellis R, Group H (2004) The monocyte chemotactic protein-1 $-2578 \mathrm{G}$ allele is associated with elevated MCP-1 concentrations in cerebrospinal fluid. J Neuroimmunol 157(1-2):193-196

34. Bradford RD, Yoo YG, Golemac M, Pugel EP, Jonjic S, Britt WJ (2015) Murine CMV-induced hearing loss is associated with inner ear inflammation and loss of spiral ganglia neurons. PLoS Pathog 11(4):e1004774

35. Teissier N, Delezoide AL, Mas AE, Khung-Savatovsky S, Bessières B, Nardelli J, Vauloup-Fellous C, Picone O, Houhou N, Oury JF, Van Den Abbeele T, Gressens P, Adle-Biassette H (2011) Inner ear lesions in congenital cytomegalovirus infection of human fetuses. Acta Neuropathol 122(6):763-774 